\title{
Geological Evolution of the Brazilian Continental Margin
}

\author{
by Haroldo E. Asmus and Paulo R. Baisch
}

This article reviews the major findings of an intensive geological and geophysical study of the Brazilian margin and adjacent oceanic and continental areas. Most of the data fits well with standard plate models for Atlantic-type margins, with clearly recognizeable pre-rift, rift, proto-oceanic and oceanic stages. However there are significant problems regarding the nature of the crust beneath the margin and the position of the boundary between oceanic and continental crust.

\begin{abstract}
Introduction
According to standard plate tectonics the Atlantic type of continental margin, including that of Brazil, should be the result of three main sequential events: uplifting and doming of the continental crust, crustal fragmentation (rifting) and lateral displacement of the fragmented continental blocks accompanied by progressive spreading of the oceanic floor and subsidence of the resulting marginal basins. Geological and geophysical data available at the start of oil exploration along the Brazilian margin (Ponte, 1971; Asmus and Porto, 1972; Asmus and Ponte, 1973) permitted identification of structural and statigraphic features conformable with this model.
\end{abstract}

During the 1970s, exploratory efforts were intensified in these basins by PETROBRÁS (the Brazilian state oil company), especially under the umbrella of a joint program with other Brazilian agencies: REMAC-Global Reconnaissance of the Brazilian Continental Margin. Deep water surveys were carried out by institutions such as Lamont-Doherty Geological Observatory, Woods Hole Oceanographic Institution, and Centre National pour l'Exploitation des Océans. As a result a considerable amount of new data was gathered, and the analysis and interpretation of more than 1500 boreholes and some $400000 \mathrm{~km}$ of multichannel seismic reflection survey lines make the Brazilian continental margin one of the best known Atlantic-type margins in the world.

Important works on the structural framework include Asmus and Ponte (1973), Gorini (1977), Alves (1981) and Guazelli and Carvalho (1981); on stratigraphy Sampaio and Northfleet (1973), Asmus and Campos (1983); on magmatic rocks, Cordani (1970), Asmus (1982a) and Lapido-Loureiro (1982); and on evolution, Almeida (1967), Asmus and Porto (1972), Asmus and Guazelli (1981) and Asmus (1982b).

All these data have led to a better knowledge of the structural and stratigraphic features of this margin. Moreover, these features can be critically compared with previous interpretations based on the plate tectonic hypothesis. Although most current models for the evolution of the Brazilian margin and, by extension, for the formation of the South Atlantic Ocean are confirmed by these data, certain other hypotheses concerning the pre-drift fitting of Brazil and Africa and the nature of the boundary between the continental and oceanic crusts are not supported. Attempts to relate submarine features such as transversal structures with observed or inferred features on the continental areas have raised problems as yet not entirely solved (Fig. 2).

Structural Features of the Brazilian Margin

Normal faults are outstanding structures in the northern (equatorial) and eastern portions of the margin (Fig. 1, Sections 1 to 4). Here the faults step downwards to the ocean with vertical displacements ranging from a few meters up to

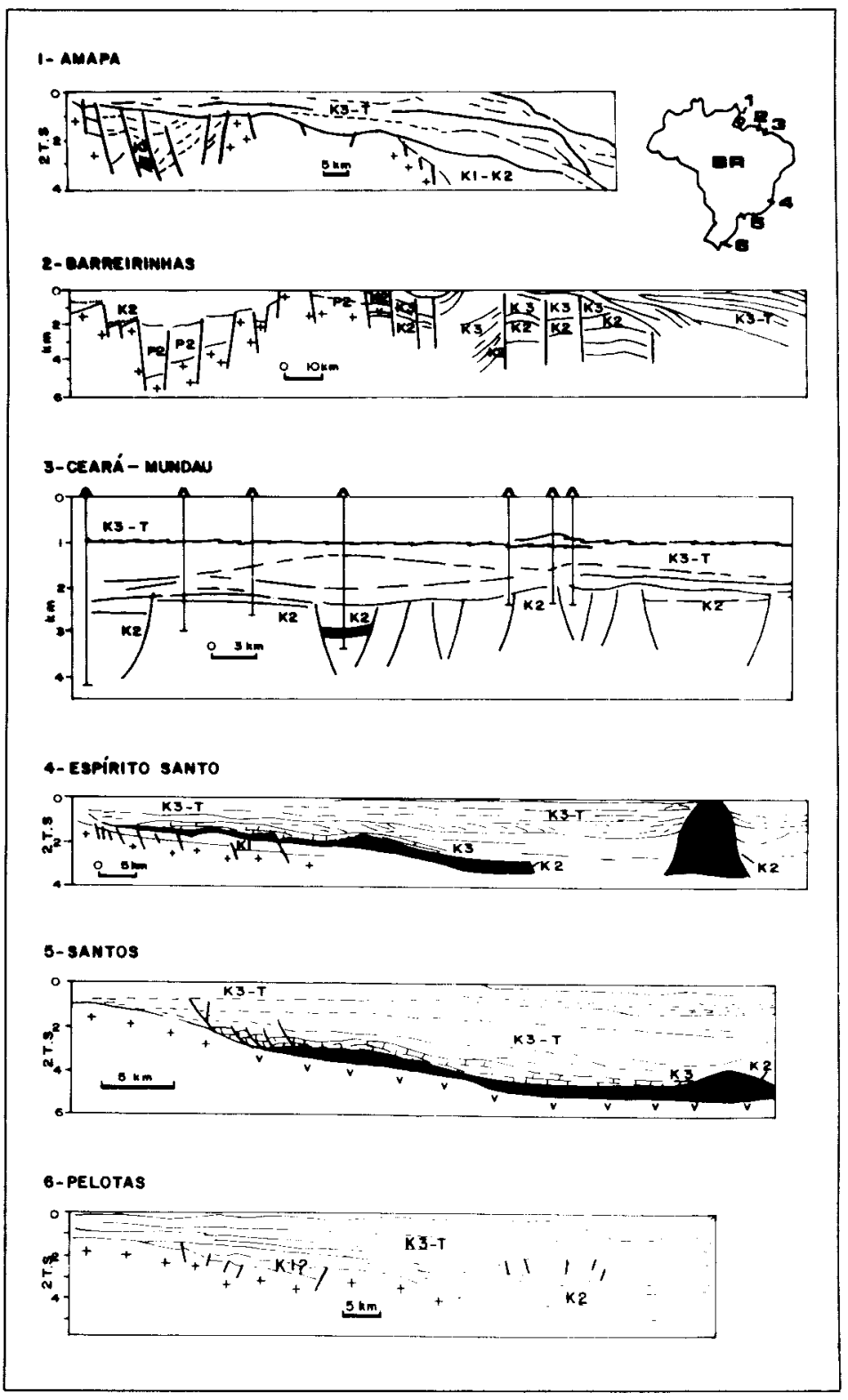

Figure 1: Geological sections across the Brazilian continental margin. 


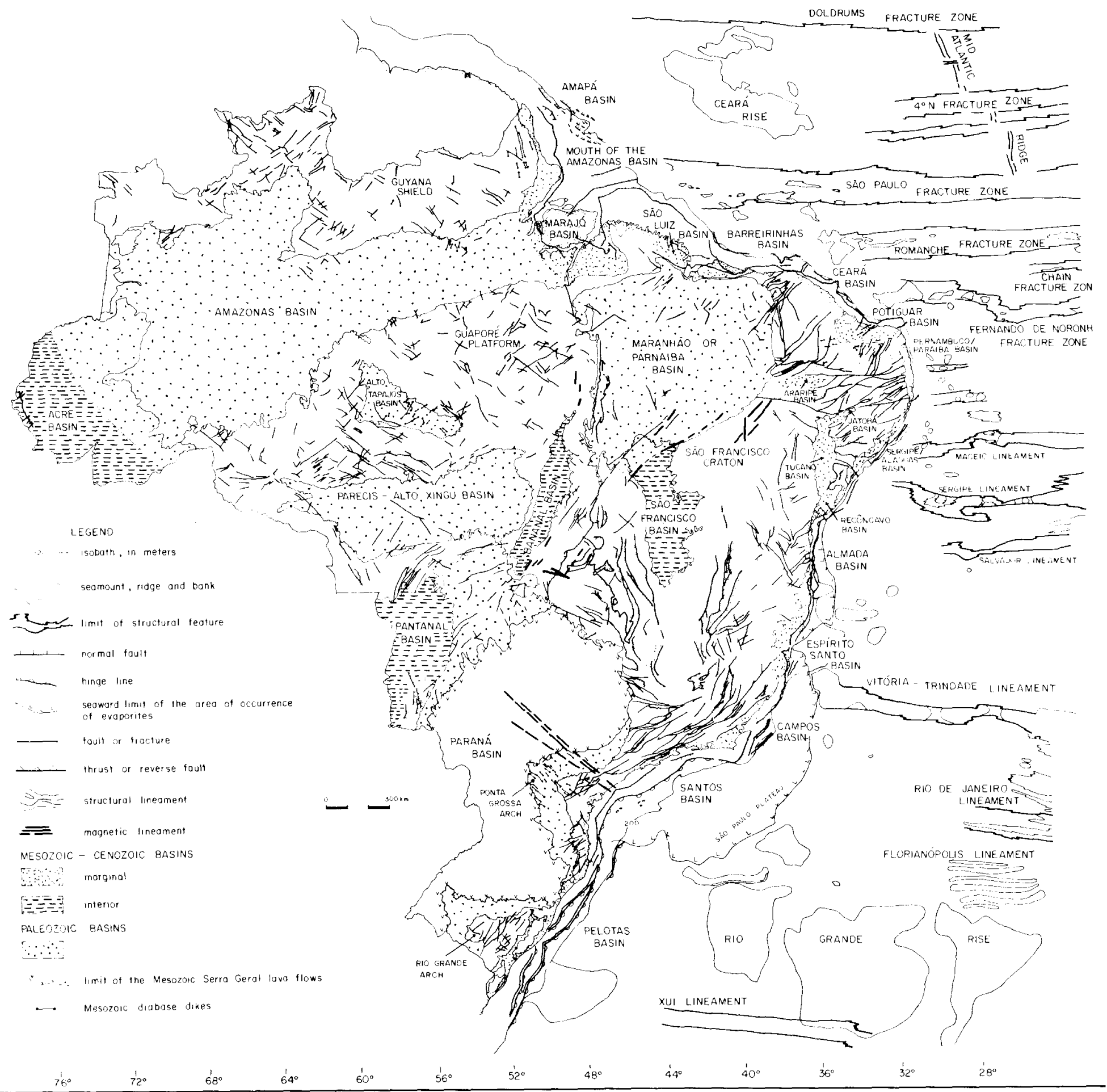

Figure 2: Geological Map of Brazil and adjoining ocean floor (Based on Schobbenhaus and others, 1981).

$3000 \mathrm{~m}$ and bounding the Mesozoic basins. In places, uplifted fault blocks separate depositional centers as exemplified by the Cabo Frio, Vitória and Florianópolis highs (Fig. 3). In the Mouth of the Amazonas and Marajó areas, and the Barreirinhas-São Luiz, the Potiguar and Recôncavo-Tucano basins, the faults control graben basins that extend far into the emerged continent to form a characteristic triple-junction framework (Fig. 2). In the southwestern part of Section 2, Figure 1, Palaeozoic $\left(\mathrm{P}_{2}\right)$ and Alagoan evaporites $\left(\mathrm{K}_{2}\right)$ represent beds deposited originally in the Maranhão interior basin and cut by faults forming the Barreirinhas Basin in Early Cretaceous times.

From the Campos to the Pernambuco-Paraiba basins the faults are ascribed to the Early Cretaceous $\left(K_{1}\right)$. In the more northerly regions most of the structures are interpreted as Alagoan $\left(\mathrm{K}_{2}\right)$ and locally Late Cretaceous $\left(\mathrm{K}_{3}\right)$, although some faulting was also initiated in $K_{1}$ times, as in the 
emerged southern part of the Potiguar Basin, or even in the Triassic, as in the Cassiporé Graben of the Amapá Basin (Fig. 1, section 2). Thus, it is important to note that faulting was still occurring in the equatorial segment of the margin at a time when the eastern margin was tectonically quiescent.

Hinge lines or flexures are linear features separating a thin sedimentary wedge to the landward from a thick section towards the ocean. These occur along the entire margin but are preponderant in the Pelotas Basin (Alagoan and Paleocene flexures - Fig. 1, section 6) and the Santos Basin (Paleocene flexure - Fig. 1, section 5), where they are associated with half-grabens. In these basins, Early Cretaceous normal faults are second-rank structures. There are however important faults in the coastal region adjoining the Santos Basin, with vertical displacements approaching $2000 \mathrm{~m}$. These are gravity faults that displace Precambrian crystalline blocks to form ridges or "serras" with crests aligned essentially parallel to the coast line, and resulting from localized Cenozoic tectonism (Almeida, 1976; Asmus and Ferrari, 1978).

Transverse structures include oceanic fracture zones and oceanic lineaments (Fig. 2), composed of east-west belts from 100 to $250 \mathrm{~km}$ in width. Although they are interpreted in reflection seismic profiles by the same diagnostic elements (irregular relief determined by an alternation of peaks and troughs in the acoustic basement, which is generally at different levels on both sides of the rugged basement), there are dissimilarities. The fracture zones, like those of São Paulo, Romanche, Chain and Fernando de Noronha can be traced continuously from the Brazilian continental margin to the West African margin in the Gulf of Guinea, cutting the central rift-valley of the Mid-Atlantic Ridge with horizontal displacements (Gorini and Bryan, 1976; Mascle, 1977). The lineaments, in contrast, cannot be traced into the oceans more than about $2000 \mathrm{~km}$ from the continental margin, and they do not appear to cross the Mid-Atlantic Ridge.

\section{Stratigraphic Features}

The sediments of the Brazilian marginal basins can be divided into discrete, large-scale intervals with different facies units indicating distinct environments of deposition. Such a division is helpful for accurate tectono-sedimentary analyses, for comprehensive regional palaeogeographic and palaeogeological reconstructions and for effective transoceanic correlations.

Using these criteria the stratigraphic column of the Brazilian margin (Fig. 3) can be shown to consist of four major stratigraphic units or sedimentary sequences, the naming of which is evocative of the general environment of their deposition: Sequence of the Continent (C), Sequence of the Lakes (L), Sequence of the Gulf $(G)$ and Sequence of the Sea (S). Seismostratigraphic analyses indicate that the tectonic and sedimentary processes along the Brazilian continental margin occurred in a systematic manner. Thus, the sedimentary infilling of the different types of basins can be associated with different tectonic environments such as pre-rift, rift, proto-oceanic and oceanic envisaged for the evolutionary history of this margin (Table 1).

The scarcity of guide fossils in the sequences of the Continent, Lakes and Gulf does not permit correlation of this part of the Brazilian stratigraphic record with the international column. However, good correlations have been obtained between Brazil and Africa (Ponte and Asmus, 1978). Britto and Campos (1983) have divided this interval into local stages, namely Donjoanian, Bahian and Alagoan (Table 1). Within the Sequence of the Sea, which includes Upper Aptian and later sediments, it is possible to establish a good correspondence with the standard column.

The Sequence of the Continent is restricted to a short portion of the eastern margin, from the Sergipe-Alagoas to the

TABLE 1: Characteristics of the Major Sedimentary Sequences.

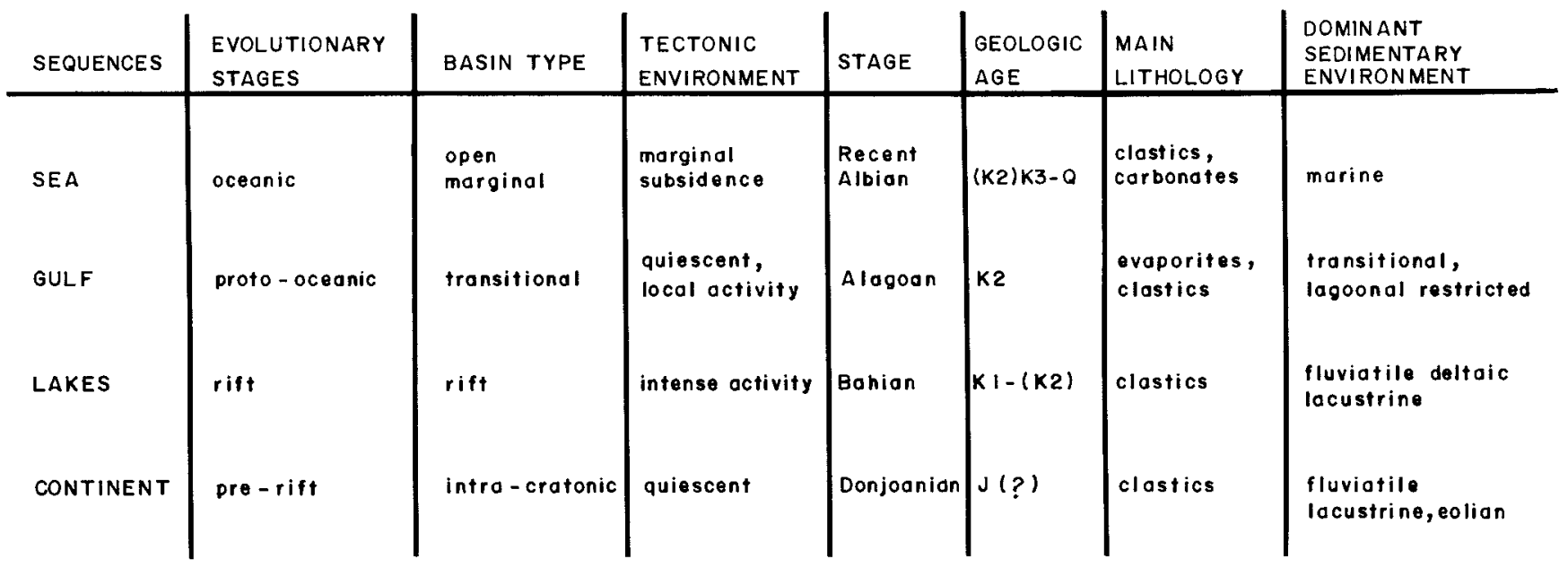

Lineaments predominate in the eastern to southern portions of the margin where five main structures occur: Maceió, Vitória-Trindade, Rio de Janeiro, Florianópolis and Xui (Fig. 2). However, oceanic fracture zones occurring in the eastern margin may have gone undetected due to the low density and/or irregular distribution of the seismic reflection tracks. Fold structures have been detected in seismic profiles in parts of the northern Brazilian margin. However, their distribution and axial directions are not yet adequately known.
Cumuruxatiba Basin. Thus, this segment is the only one along the entire Brazilian margin that shows a complete column representative of the standard Atlantic type of margin. With the exception of the Pelotas, Florianópolis and Santos Basins, the Sequence of the Lakes is recognized in all of the other marginal basins. However, in the Santos Basin it seems to be restricted in occurrence and thinner than in northern and eastern basins. Most of the wells drilled in the Santos Basin show that the Alagoan evaporites lie directly upon weathered Early Cretaceous basalts some 100 to $120 \mathrm{Ma}$ old. 


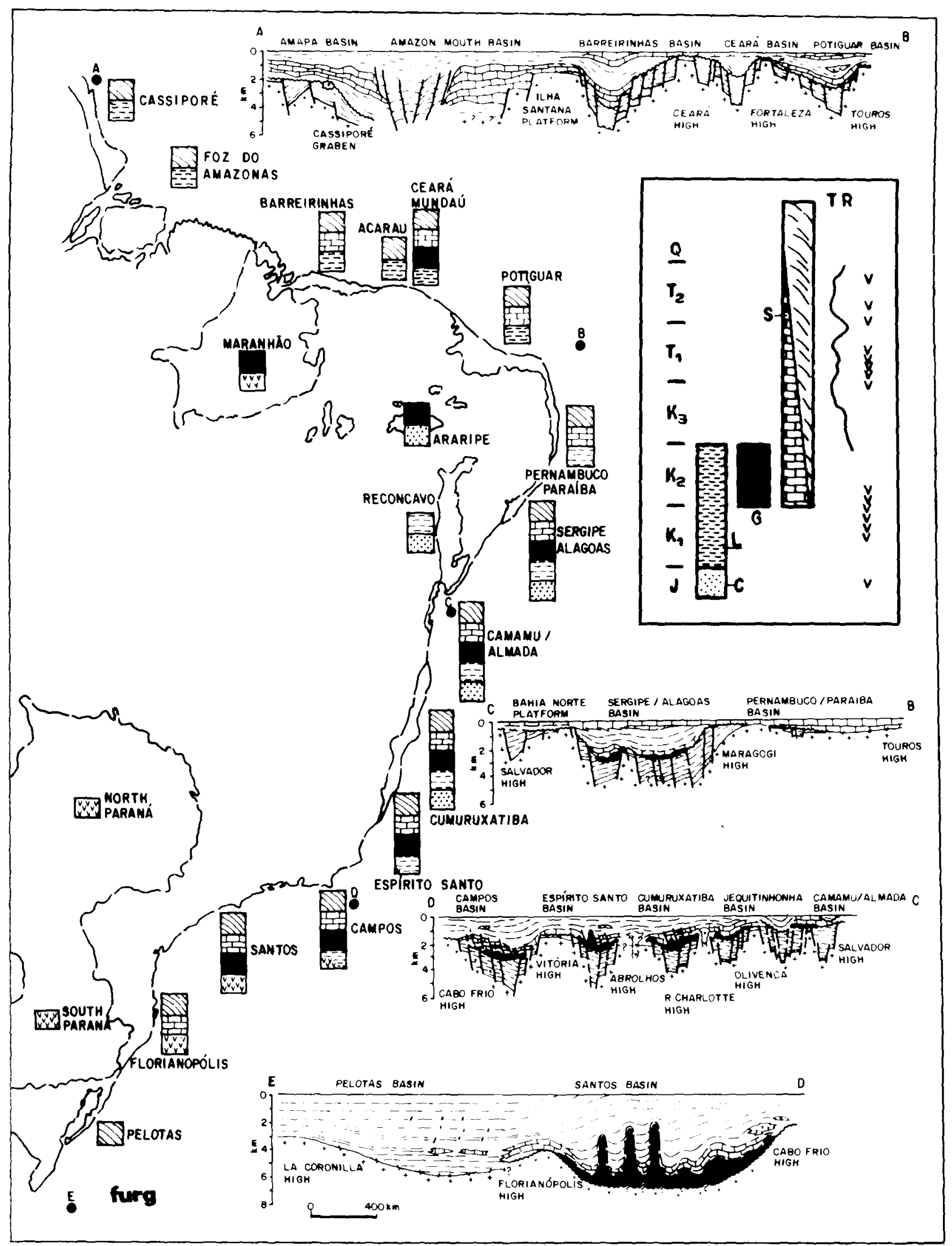

Figure 3: Stratigraphy of the Brazilian marginal basins. $J$-Jurassic; $\boldsymbol{K}_{\mathbf{1}}$ - Lower Cretaceous (Bahian); $\boldsymbol{K}_{\mathbf{2}}-\mathrm{Lower}$ Cretaceous (Alagoan); $K_{3}$ - Albian to Maestrichtian; $T$ - Tertiary. The curve to the right of the columnar legend indicates the main marine transgressions $(T)$ and regressions $(R)$. $v$ represents intercalations of igneous rocks. 
Evaporites of the Sequence of the Gulf appear continuously from the Santos to the Sergipe-Alagoas Basin. The evaporites cover the whole of the São Paulo Plateau, and occupy a triangular area with a $600 \mathrm{~km}-$ long base immediately to the north of the Florianópolis Lineament and an apex in the Sergipe-Alagoas Basin (Fig. 2). Along the northern margin, these evaporites appear as localized spots in the Ceará and Araripe Basins and in the predominantly Palaeozoic Maranhão Basin. In these basins the Early Cretaceous evaporites are cut by normal faults that form the rift stage of the marginal basins (Fig. 1).

The Sequence of the Sea is ubiquitous, and has a considerable thickness in almost all of the basins, ranging to about 13000 $\mathrm{m}$ in the Amazonas Mouth Basin. Only in the PernambucoParaiba Basin, which is actually an uplifted crustal block, is the thickness of this sequence less than $2000 \mathrm{~m}$.

\section{Magmatic Rocks}

Figure 4 shows the distribution of the Mesozoic-Cenozoic basaltic and alkaline magmatic rocks in three areas of Brazil, each one including portions of the continental margin. The dominance of magmatic activity in area $A$ is obvious, with more than $10^{6} \mathrm{~km}^{2}$ covered by lava flows as thick as $1600 \mathrm{~m}$. This magmatism apparently extended to the Santos and Campos basins during the Early Cretaceous.

Also within area $\mathrm{A}$ on Figure 4 are many alkaline volcanics on the continent and basaltic volcanics in the continental margin with ages clustered between 90 and $40 \mathrm{Ma}$. The most intensive magmatic activity in this period, both in the emerged and submarine areas, occurred along the same latitudinal belts in which the Vitória-Trindade, Rio de Janeiro and Florianópolis lineaments are situated and also along the axis of the Ponta Grossa Arch (Fig. 2).

In area $B$, the volcanic sites are less numerous and more uniformly distributed than in area $A$. In the marginal basins, a basaltic-granitic complex (130-90 Ma) in the PernambucoParaiba Basin and 40-20 Ma old basaltic rocks in the Potiguar Basin are the most important occurrences. In area $\mathrm{C}$, the few magmatic rocks that occur in the continental margin are older than 90 Ma: in the Cassiporé Graben of the Amapá Basin basalts have been dated at $206 \mathrm{Ma}$.

\section{Pre-Rift Stage}

The distribution of the Sequence of the Continent suggests that the portions of the Brazilian margin now occupied by the Pelotas, Santos, Campos, Espírito Santo, Pernambuco-Paraiba and Equatorial Basins, formed positive areas in the Late Jurassic (Donjoanian) (Fig. 5A). Within this framework the area of the Santos Basin was more strongly uplifted than the surrounding regions, as attested by the Ponta Grossa Arch (Fig. 2) which is considered a transversal appendix of the main dome. Indications of an isotopic homogenization $180 \mathrm{Ma}$ ago in the Paraná Basin (Thomaz Fo. et al., 1976) and the records of extensive Early Cretaceous volcanism support the inference that a "lithothermal" event caused the uplifting of the southeastern margin.

Martin (1976) and Siedner and Mitchell (1976) have described a Triassic-Jurassic uplift in Southwest Africa in a position that is currently occupied by the remnants of an extensive Early Cretaceous (120 Ma old) basaltic magmatism. This African dome matches the Santos uplift. Elsewhere in Brazil, however, topographic highs appear to have been related to inhomogeneities in crustal thickness, for there are no indications in these areas of Late Jurassic thermal anomalies or of Early Cretaceous volcanic activity.

\section{Rift-Valley Stage}

Rupture of the crust then formed rift-type basins with varying structural characteristics and intensity of penecontemporaneous volcanism (Fig. 5B). These differences appear to be related to the position of the rift basins with respect to the existing relief in the preceding stage.
In the Santos Basin (Fig. 1, section 5), the rift-bounding faults are not as well developed as in the other eastern basins (e.g. Sergipe-Alagoas Basin), and sections of the Sequence of the Lakes are very restricted. Such characteristics typify the arch-volcanic type of $\mathrm{rift}$ in Milanowsky's classification (1972). The other rift basins, according to the same classification, are included in the crevice type of rift. These are deep tectonic basins bounded by faults with large vertical displacements and filled with thick fluviatile-deltaic and lacustrine sediments. Volcanic activity, if present, was of minor importance.

The rifts of the equatorial region are of the transcurrent type, formed by faults younger in age than those of the eastern margin. The former cut Alagoan or even younger beds $\left(\mathrm{K}_{3}\right)$ (Fig. 1 , sections 2 and 3 ), whereas in the eastern margin the rift-bounding faults cut only pre-salt $\left(K_{1}\right)$ sediments.

\section{Proto-oceanic Stage}

Crustal distension and necking during the rift stage led to the formation of a relatively narrow and elongate basin separating eastern Brazil and western Africa and floored by a continental-transitional type of crust. The first marine invasion into this zone formed a gulf-like embryonic ocean (Fig. 5C). Volcanic activity along transversal crustal fractures (Florianópolis Lineament-Walvis Ridge), however, created barriers to the free circulation of sea waters. The prevailing arid climatic conditions resulted in the deposition of evaporites from the Santos to Sergipe-Alagoas marginal
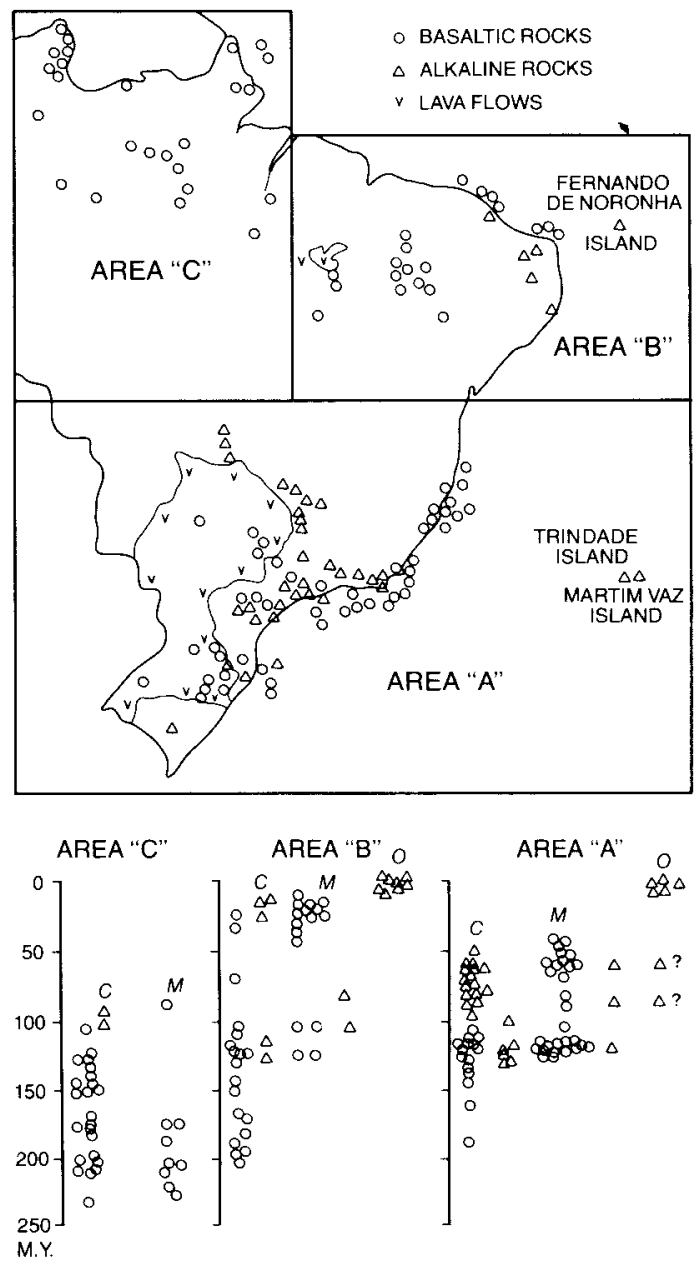

Figure 4: Distribution and age range of Mesozoic and Cenozoic igneous rocks. $\mathbf{C}$ - continental rocks; $\boldsymbol{M}$ marginal basins; $\mathbf{O}$ - oceanic islands. 
basins on the Brazilian side and from the Cuanza to Gabon Basins on the African side. Local restrictions in circulation also favoured the deposition of evaporites in small interior Maranhão, Araripe and Ceara basins.

\section{Oceanic Stage}

An open marine environment developed in the Albian. Presumably this oceanic stage resulted from the lateral movement of Brazil relative to Africa and the associated generation of oceanic crust (Fig. 5D). At this time lateral post-rift movements in the eastern margin corresponded to the rifting process in the equatorial sector. This situation occurred because, on the basis of the accepted model, the main eastwest stresses responsible for the lateral movement of the fragmented blocks were perpendicular to the borders of the eastern embryonic pull-apart margin, but parallel to the equatorial segment of the sheared or transcurrent margin (Fig. 5D). In the latter region the stress couple was capable of fragmenting the crust into rift basins and of creating localized compressional features.

In the eastern margin, this oceanic stage was characterized by tectonic quiescence with crustal subsidence of the margin and uplifting of the coastal area without rupture (Walcott, 1972). Thus, the Cenozoic tectonism in the southeastern region, especially in the Santos Basin adjoining the São Paulo Embayment, stands out as an exception. Asmus and Ferrari (1978) interpreted this tectonism as a late response to the Triassic-Jurassic thermal event that took place in the site of the present Santos Basin.

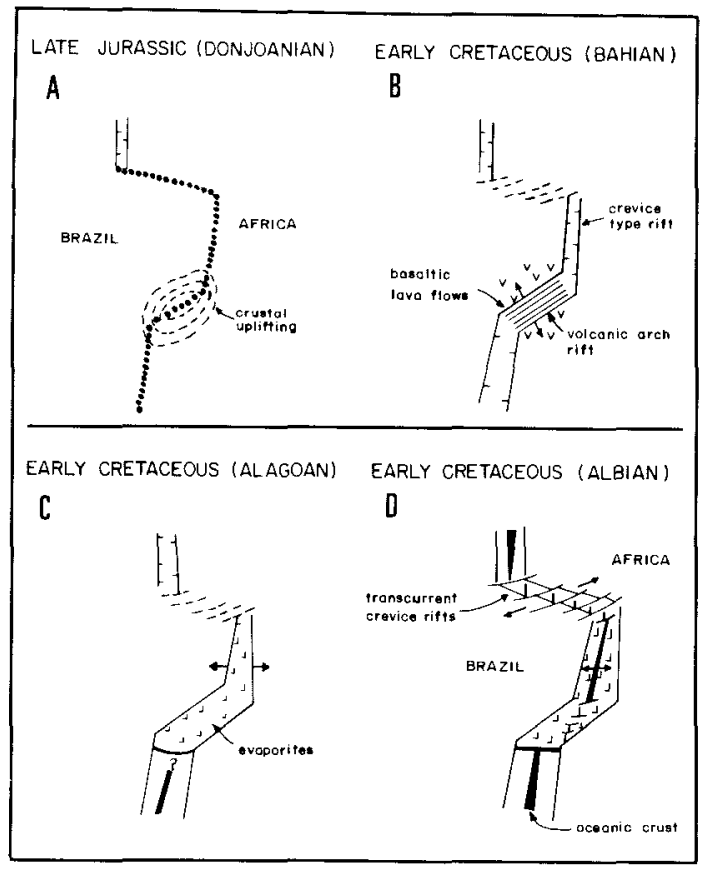

Figure 5: Schematic reconstructions of the initial evolutionary stages of the Brazilian continental margin.

\section{Discussion}

The opening of the Brazilian margin took place along a belt of irregular relief involving uplifted and subsided areas. Such a topographic situation is thought to have been created one way or another by differences in crustal thicknesses, compositional inhomogeneities and localized intrusions of lithothermal systems. To a first approximation these inhomogeneities and thermal anomalies can be linked to the distribution of ancient cratonic and folded areas (Sykes, 1978; Asmus and Porto, 1980; Asmus, 1982a).

Several consequences can be ascribed to these crustal inhomogeneities. First, in the emerged continent, they have controlled linear zones of crustal instability. These are particularly well observed in southeastern Brazil at sites of recent seismic activity (Sykes, 1978; Assumpção and others, 1980), and magmatism which recurred between the Early and Late Cretaceous and in the Early Tertiary (Asmus, 1982a). These sites occur in aligned east-west strips coinciding with the flanks of the inferred Triassic-Jurassic thermal uplifts.

Along the continental margin the main oceanic lineaments occupy latitudinal belts that correspond to structural highs in the continental shelf and/or to essentially east-west aligned strips bounding uplifted and subsided crustal blocks in the emerged continent. Examples of this situation include the Maceió Lineament-Maragogi High separating the shallow Pernambuco-Paraiba Basin and the deep Sergipe-Alagoas Basin (Fig. 3, section BC); the Rio de Janeiro Lineament - Cabo Frio High (Fig. 3, section CD) - northern flank of the Ponta Grossa Arch (Fig. 2); the Florianópolis Lineament - Florianópolis High (Fig. 3, section DE) - southern flank of the Ponta Grossa Arch (Fig. 2); and the Xui Lineament - La Coronilla High (Fig. 3, section DE) - southern flank of the Rio Grande Arch (Fig. 2).

The correspondence of the Vitória-Trindade Lineament with a coastal megastructure is not evident. However, the west ward extension of the latitudinal belt in which this lineament occurs coincides with the Vitoria High in the continental margin (Fig. 3, section CD) and with the boundary between an old (2 200-1800 Ma) cratonic area (São Francisco Craton) (Fig. 2) and a younger ( $550 \mathrm{Ma}$ ) folded belt in the emerged continent (Sykes, 1978). All these examples suggest that the pre-existing zones of weakness separating continental crustal blocks, and supposedly responsible for the recurrent magmatism and seismic processes, can also be considered as the ultimate control on the formation of the oceanic lineaments. The latter can then be considered as secondary transversal structures. Since the same relationships are not clearly observed in the oceanic fracture zones, these are classified as primary transversal structures.

However, some complications to the application of the continental drift hypothesis appear when one considers the possible continuity of these oceanic transversal structures into the transcontinental deep lithospheric fracture zones (e.g. the equatorial fracture zones to the Amazonas Palaeozoic Basin and the Huancabamba Deflection or the Florianópolis Lineament to the Ojos del Salado Lineament).

Considering that locally in the Santos Basin as well as in the Campos basins, Alagoan evaporites overlie $120 \mathrm{Ma}$ old basaltic lava flows, it is possible to say that the drifting of Brazil and Africa did not begin before $120 \mathrm{Ma}$ ago. As regards the ocean spreading stage, data on the marginal basins, principally the ages of faulting, indicate that the lateral movement of Brazil relative to Africa took place after the deposition of the Alagoan salt in the South Atlantic protoocean. This implies that the salt rests on an originally continental crust in the São Paulo Plateau, whose maximum width is $600 \mathrm{~km}$ in the area adjoining the Santos Basin. On the basis of geophysical data, Kowsmann and others (1982) have corroborated the continental/intermediate nature of the crust beneath the São Paulo Plateau. Moreover, a typical continental rock occurring as a xenolith in alkaline volcanics in the Fernando de Noronha Archipelago (Fig. 4 and Figueiredo et al., 1982) - a group of islands located in a supposedly oceanic crust - suggests that a wide strip of continental crust may exist along the Brazilian margin.

The discovery of an originally continental crust beneath the São Paulo Plateau and possibly farther to the north implies that the contact between continental and oceanic crusts in the submarine areas of $\mathrm{f}$ the Brazilian territory lies farther from the coast and at a deeper water depth than those suggested previously (e.g. Bullard and others, 1965).

\section{Acknowledgments}

The authors wish to thank Dr. Aarne Iivari Munne for helpful review of the text. 
H.E. Asmus is Professor of Geology at the University of Rio Grande, (C.P. 474, 96200 Rio Grande, R.S., Brazil), and a former staff member of PETROBRÁs from 1960 to 1980 . He is a member of the Brazilian Geodynamic Commission and President of the Geotectonic Commission of the Brazilian Geological Society. His research interests include the geology and evolution of the Brazilian continental margin.

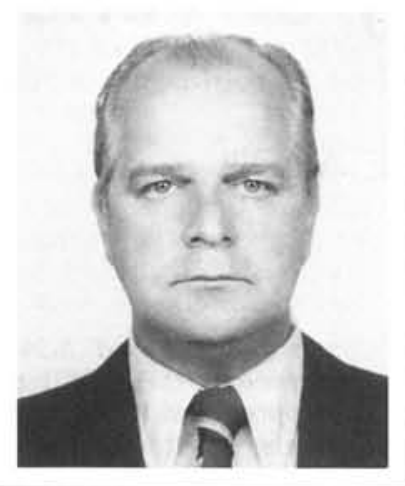

P.R. Baisch has been a Professor of Geology at the University of Rio Grande since his graduation in 1979. His recent research interests have concentrated on geochemistry of sediments and particulates in estuarine and open sea waters.

\section{References}

Almeida, F.F.M., 1967. Origem e evolução da plataforma brasileira. Brazil. Divisão de Geologia e Mineralogia, Boletim 241, 36p.

Almeida, F.F.M., 1976. The system of continental rifts bordering the Santos Basin, Brazil. Anais Da Academia Brasileira De Ciências, 48 (Supplemento), p. 15-26.

Alves, E.C., 1981. Estruturas da margem continental sul Brasiliera e das áreas oceânicas e continentais adjacentes. Rio de Janeiro, Série Projeto REMAC, 9, p. 145-170.

Asmus, H.E., 1978. Hipóteses sobre a origem dos sistemas de zonas de fratura oceânicas/alinhamentos continentais que ocorrem nas regiões Sudeste e Sul do Brasil. Série Projeto REMAC, Rio de Janeiro, 4, p. 39-73.

Asmus, H.E., 1982a. Geotectonic significance of Mesozoic-Cenozoic magmatic rocks in the Brazilian continental margin and adjoining emerged area. 5 Congreso Latinoamericano de Geologia, Argentina, 1982, Actas, III, p. 761-779.

Asmus, H.E. 1982b. Características estruturais e estratigráficas da margem continental brasileira como elementos críticos do modelo de sua evolução. 5 Congreso Latinoamericano de Geologia, Argentina, 1982, Actas, III, p. 781-798.

Asmus, H.E. and Campos, D.A., 1983. Stratigraphic division of the Brazilian continental margin and its paleogeographic significance. 2 Symposium Kreide, München, 1982, Zitteliana, v. 10, p. 265-276.

Asmus, H.E. and Carvalho, J.C., 1978. Condicionamento tectônico da sedimentação nas bacias marginais do Nordeste do Brasil (Sergipe-Alagoas e Pernambuco-Paraiba). Série Projeto REMAC, Rio de Janeiro, 4, p. 7-24.

Asmus, H.E. and Ferrari, A.L., 1978. Hipótese sobre a causa do tectonismo cenozóico na região Sudeste do Brasil. Série Projeto REMAC, Rio de Janeiro, 4, p. 75-88.

Asmus, H.E. and Guazelli, W., 1981. Descricão sumária das estruturas da margem continental brasileira das áreas oceânicas e continentais adjacentes: hipóteses sobre o tectonismo causador e implicações para os prognósticos do potencial de recursos minerais. Série Projeto REMAC, Rio de Janeiro, 9, p. 187-269.

Asmus, H.E. and Ponte, F.C., 1973. The Brazilian marginal basins. In: Nairn, A.E.M. and Stehli, F.G. (eds.), The Ocean Basins and Margins, v. 1, The South Atlantic, p. 87-133, New York, Plenum Press.
Asmus, H.E. and Porto, R., 1972. Classificação das bacias sedimentares brasileiras segundo a tectônica de placas. XXVI Congresso Brasileiro Geologia, Belém, 1972, Anais, 2, p. 67-90.

Asmus, H.E. and Porto, R., 1980. Diferenças nos estágios iniciais da evolução da margem continental brasileira: possíveis causas e implicações. XXXI Congresso Brasileiro Geologia, Balneário de Camboriú, Brazil, 1980, Anais, 1, p. 225-239.

Assumpção, M. et al., 1980, Sismicidade do Sudeste do Brasil. Balneário de Camboriú, 1980, Anais, 2, p. 1075-1092.

Britto, I.M. and Campos, D.A., 1983. The Brazilian Cretaceous. 2 Symposium Kreide, München, 1982, Zitteliana, v. 10, p.277.

Bullard, E., Everett, J.E. and Smith, A.G., 1965. The fit of the continents around the Atlantic. Royal Society of London, Philosophical Transactions, Se. A, 258, p. 41-51.

Cordani, U.G., 1970. Idade do vulcanismo no Oceano Atlântico Sul. Boletim Instituto de Geociências e Astronomia, Universidade de São Paulo, 1, p. 9-75.

Figueiredo $F^{\circ}$., O.A., Miranda, F.M., Soares, U.C., Petta, R.C. and Conceição, L.A.Z., 1982. Considerações sobre o "Xenóli to Granitico" de Fernando de Noronha. Bol. Dept. Geol., Univ. Rio Grande do Norte, 6, p. 9-12.

Gorini, M.A., 1977. The tectonic fabric of the Equatorial Atlantic and adjoining continental margins: Gulf of Guinea to Nor theastern Brazil. Série Projeto REMAC; Rio de Janeiro, 9, p. 11-116.

Gorini, M.A. and Bryan, G.M., 1976. The tectonic fabric of the Equatorial Atlantic and adjoining continental margins, Gulf of Guinea to Northeastern Brazil. Anais Academia Brasileira de Ciências, 48 (Suplemento), p. 101-119.

Guazelli, W. and Carvalho, J.C.de, 1981. Estruturas da margem continental leste brasileira e das áreas emersas e oceânicas adjacentes. Série Projeto REMAC, Rio de Janeiro, 9, p. 117-143.

Kowsmann, R.O., Costa, M.P.A., Almeida, H.P., Guimaraea, P.P.D. and Boa Hora, M.P.P., 1982. Geologia estrutural do Platô de São Paulo. XXXII Congr. Bras. Geol., Salvador, 1982, Anais, 4, p. 1558-1569.

Lapido-Loureiro, F.E. and Valderano, M.H.W. di, 1982. A província alcalino carbonática Brasil-Angola e seus principais aspectos econômicos. XXXII Congr. Bras. Geol., Salvador, 1982, Anais, 3, p. 1049-1060.
Loczy, L. de, 1969. Tectonismo transversal na constituição da América do Sul e a importância econômica das falhas transcorrentes. Mineração e Metalurgia, 50 (300), p. 273280.

Martin, H., 1976. A geodynamic model for the evolution of the continental margin of Southwest Africa. Anais Academia Brasileira de Ciências, 48 (Suplemento), p. 169. 177.

Mascle, J., 1977. Le Golfe de Guinée (Atlantique Sud): un exemple d'évolution des marges atlantiques en cisaillement. Mémoire Société Géologique de France, Nouvelle, Serie, 45, Mémoire 128, p. 1-102.

Milanovsky, E.E., 1972. Continental rift zones: their arrangement and development. Tectonophysics, 15, no. 1-2, p. 65-70.

Ponte, F.C. (ed.), 1971. Evolução Paleogeográfica do Brasil Oriental e Africa Ocidental. Petrobrás (internal report), 7lp.

Ponte, F.C. and Asmus, H.E., 1978. Geologic framework of the Brazilian continental margin. Geologische Rundsschau, 67, no. 1, p. $201-235$.

Sampaio, A.V. and Northfleet, A.A., 1973. Estratigrafia e correlação das bacias sedimentares brasileiras. XXVII Congr. Brasil. Geol., Aracaju, 1973, Anais, 3, p. 189-206.

Schobbenhaus, C., Campos, D.A., Derze, G.R. and Asmus, H.E., 1981. Mapa geológico do Brasil e da área oceânica adjacente incluindo depósitos minerais, Escala 1:2500000, Deptartamento Naçional da Produção Mineral, Brasilia, 4 sheets.

Siedner, G. and Mitchell, J.G., 1976. Episodic Mesozoic volcanism in Naimibia and Brazil: a $\mathrm{K}-\mathrm{Ar}$ isochron study bearing on the open ing of the South Atlantic. Earth and Planetary Science Letters, 30, no. 2, p. 292-302.

Sykes, L.R., 1978. Intraplate seismicity, reactivation of preexisting zones of weakness, alkaline magmatism, and other tectonism postdating continental fragmentation. Reviews of Geophysics and Space Physics, 16 (4), p. 621-688.

Thomaz $F^{\circ}$, A., Cordani, U.G. and Kawashita, K., 1976. Aplicação do método $\mathrm{Rb} / \mathrm{Sr}$ na datação de rochas sedimentares argilosas da Bacia do Paraná. XXIX Congr. Brasil. Geol., Ouro Preto, 1976, Anais, 4, p. 289. 302.

Walcott, R.I., 1972. Gravity, flexure and the growth of sedimentary basins at a continental edge. Geological Society of America Bulletin, 83, no. 6, p. 1845-1848. 